\title{
Correction To: Obesity, More than a 'Cosmetic' Problem. Current Knowledge and Future Prospects of Human Obesity Genetics
}

\author{
Shabana $^{1} \cdot$ Shahida Hasnain ${ }^{1,2}$ \\ Published online: 13 July 2020 \\ (c) Springer Science+Business Media, LLC, part of Springer Nature 2020
}

\section{Correction To: Biochemical Genetics (2016) 54:1-28 https://doi.org/10.1007/s10528-015-9700-2}

The authors regret that the reference provided to Fig. 1 of their publication was incorrect in the original publication. The authors obtained permission to reprint Fig. 1 retrospectively. The correct reference is: Nat Rev Genet. 2005 Mar;6(3):221-34. https://doi.org/10.1038/nrg 1556

Publisher's Note Springer Nature remains neutral with regard to jurisdictional claims in published maps and institutional affiliations.

The original article can be found online at https://doi.org/10.1007/s10528-015-9700-2.

\section{Shabana}

shabana.mmg@pu.edu.pk

1 Department of Microbiology and Molecular Genetics, University of the Punjab, Lahore 54590, Pakistan

2 The Women University Multan, Multan, Pakistan 